\title{
MINIMUM WAGES AS AN OBSTACLE TO THE FREE PROVISION OF SERVICES
}

\begin{abstract}
Melita Carević, Paula Kiš, Filip Kuhta*
Summary: This article deals with the question of the extent to which the national regulation of minimum wages is influenced by the European Community's legal order. Firstly, it analyses the case law of the European Court of Justice with regard to Article 49 of the EC Treaty, which indicates that there is an increasing tendency to restrict the ability to extend a host state's minimum wage to foreign service providers. It then examines the Posted Workers Directive in the light of the Laval and Rüffert cases, which are seen as unexpected interpretations of the Directive and which will have an influence on the social models of some Member States. Finally, the article focuses on Croatia as a Non-Member State and its obligations, which derive from the Stabilisation and Association Agreement, regarding the Posted Workers Directive.
\end{abstract}

The European Union is a territory of 27 social systems and each system is a different species. Thus, there are 27 minimum wage rates and 27 ways of establishing them. Undertakings which try to provide their services in another Member State with their own workers have to comply with the minimum wages of the host Member State. Therefore, changing the place of their work entails a change in their expenses with regard to their workforce. In addition, employers have to become acquainted with the different models of establishing minimum wages. Overall, an obligation to comply with the minimum wage in the host Member State is an additional burden for foreign service providers. Such a restriction, however, was considered by the Court to be a justified restriction, at least in principle. Yet, there are some exceptions, the development of which can be followed through the Court's case law from Rush Portuguesa to Dirk Rüffert. The purpose of this article is to show to what extent Member States are free to impose their wages on foreign service providers. We shall firstly analyse the case law in relation to Article 49 of the Treaty establishing the European Community, then the Posted Workers Directive 96/71/EC and afterwards the case law in the light of the Directive. Finally, we shall describe the present situation in Croatia regarding minimum wages and show how it conforms to the free provision of services.

\footnotetext{
"Melita Carević, student at the Faculty of Law of the University of Zagreb, Croatia; Paula Kiš, student at the Faculty of Law of the University of Zagreb, Croatia; Filip Kuhta, student at the Faculty of Law of the University of Zagreb, Croatia.
} 


\section{Minimum wages and Article 49 in the Court's case law}

The question of minimum wages and their influence on free movement arises specifically in the context of the free provision of services. Undertakings established in one Member State have the right to provide their services in another Member State and then return to their home state (their service is only temporary so they cannot fall under rules relating to establishment). ${ }^{1}$ This right encompasses the right to move to another Member State with their entire workforce. The Court took this stance in Rush Portuguesa, ${ }^{2}$ which was a case concerning an undertaking established in Portugal constructing railway lines in France. For this purpose it did not use French workers but its own workers. The Court found that the French law precluding foreign service providers from using their own workforce was discriminatory since domestic service providers could use their workforce without restrictions. ${ }^{3}$

In the same judgement, the Court also confirmed that Member States are free to extend their legislation or collective agreements to posted workers. As Barnard notices, ${ }^{4}$ the Court, by allowing the extension of Member States' legislation, referred to the question of social dumping. If it had precluded the extension, it would have allowed undertakings from Member States with lower social standards to gain a competitive advantage in Member States with higher ones (even though Rush Portuguesa did not concern minimum wages specifically). This approach is restricted in the Court's later judgements where it treats the extension of national legislation as a restriction on the free provision of services, which is in principle justified but is still subject to certain restrictions and, of course, to the proportionality test.

\section{Arblade - setting down the first rules of the game}

One of the first cases where the Court found that Member States may impose their minimum wages on foreign employers was Arblade. ${ }^{5}$ This

\footnotetext{
1 According to the Court in Case C-55/94 Gebhard v Consiglio dell'Ordine degli Avvocati e Procuratori di Milano [1995] ECR I-04165, if an undertaking were to provide services regularly in one Member State, then it would be considered as established in that Member State and would have to comply with all of its legislation such as legislation on minimum wages.

2 Case C-113/89 Rush Portuguesa Ld ${ }^{\underline{a}} v$ Office national d'immigration [1990] ECR I-01417.

3 The workers of the Portuguese service provider were actually third country nationals. France had some restrictions on these kinds of workers while for French service providers these restrictions did not apply.

4 Catherine Barnard, The Substantive Law of the EU: The Four Freedoms ( $^{\text {nd }}$ edn Oxford University Press, 2007) 369.

5 Joined cases C-369/96 and C-376/96 Criminal proceedings against Jean-Claude Arblade and Arblade \& Fils SARL (C-369/96) and Bernard Leloup, Serge Leloup and Sofrage SARL (C-376/96) [1999] ECR I-08453.
} 
was a case concerning a French undertaking constructing a complex of silos in Belgium. During construction, representatives from the Belgium Social Law Inspectorate requested that Arblade produce the relevant social documents. Arblade and Leloup were prosecuted for not being able to produce them on the construction site and for paying their workers a wage which was lower than the minimum wage fixed by the collective agreements declared universally applicable. In their defence, Arblade and Leloup argued that they only had to comply with French legislation, since they were established in France and that the Belgian legislation regarding minimum wages and social documents was contrary to Articles 59 and 60 of the Treaty. ${ }^{6}$ The Court took the same stance as in Rush Portuguesa: Member States are free to extend their legislation and collective agreements regarding minimum wages to employers providing services within their territory. On the other hand, the Court restricted this right to an extension in two ways. Firstly, the Belgian authorities had to recognise certain pecuniary advantages guaranteed to posted workers as a part of the minimum wage. As a result, the level of the French minimum wage was closer to the Belgian wage. Secondly, the Court precluded criminal prosecution in cases when legislative provisions concerning minimum wages are insufficiently precise and accessible. Member States just have to ensure legislation on minimum wages for foreign employers is as simple as possible. This is one of the reasons why the Court restricted the exercise of the fundamental right to strike in the Laval case. ${ }^{7}$

To summarise, Arblade is the confirmation of Member States' right to impose minimum wages on foreign employers. However, the Court at the same time tried to achieve a balance. Such an approach by the Court is more beneficial for new Member States with lower minimum wages. By recognising certain pecuniary advantages that posted workers are being paid as a part of a minimum wage, the Court decreased the difference between the minimum wage of a home Member State and host Member State. For this reason, employers do not have to increase the wages of their workers as much as the host Member States would like them to.

In addition, the principle of legal certainty as regards legislation on minimum wages ensures that foreign service providers may plan their expenses before they start providing their services in another Member State. In this way, the Court tried to facilitate the position of service providers, which find it very hard to become acquainted with often complex

\footnotetext{
6 Now EC Treaty (Treaty of Rome) articles 49 and 50.

7 Case C-341/05 Laval un Partneri Ltd v Svenska Byggnadsarbetareförbundet, Svenska Byggnadsarbetareförbundets avdelning 1, Byggettan and Svenska Elektrikerförbundet [2007] ECR 00000.
} 
systems for establishing minimum wages and quite harsh punishments if they break these rules. ${ }^{8}$

\section{Mazzoleni - adding some balancing}

Although the proportionality test was mentioned as a requirement for any restriction on the freedom to provide services in Arblade, it was not until Mazzoleni $i^{9}$ that it was used for minimum wages. Mr Mazzoleni was the owner of a company called ISA which was established in France and which sent security officers to shopping malls in Belgium. Again, posted workers were paid the French minimum wage and not the Belgian one. To distinguish his situation from that in Arblade, Mr Mazzoleni argued that his workers, although paid a wage lower than the minimum, enjoyed protection that was essentially comparable to that of Belgian workers. He based this claim on the fact that taxation in France was lower than in Belgium and therefore French workers were protected essentially the same as Belgian ones. The Court held that this was a special circumstance of an undertaking established in a frontier region. Thus, Member States in certain circumstances such as this one have to assess whether the extension of their minimum wage is necessary and proportionate. When making such an assessment, they have to take into account the overall position of a posted worker and include not only the wage but also the taxation which he or she is obliged to pay as well as social security contributions. Otherwise, imposing the domestic minimum wage might not be proportionate to the attainment of the legitimate objective of protecting workers. In other words, it is presumed that pursuing the legitimate objective of protecting workers is proportionate only if the overall protection of posted workers is not better than that of domestic ones. Therefore, the lowest level of protection guaranteed to domestic workers becomes the highest level of protection which can be sought for posted ones (by enacting the Posted Workers Directive it will become the lowest level as well).

In addition, the Court took into consideration the position of the service provider more specifically. It held that national rules might result in a disproportionate burden if the employer would have to calculate the wages on an hourly basis depending on which Member State the employee performs his or her work in. Therefore, the additional protection of workers might be too small to justify an additional administrative bur-

\footnotetext{
8 Any simplifications of their obligations become even more important for them when one bears in mind that services are always provided for a limited period of time in another Member State.

9 Case C-165/98 Criminal proceedings against André Mazzoleni and Inter Surveillance Assistance SARL, as the party civilly liable, third parties: Eric Guillaume and Others [2001] ECR I-02189.
} 
den imposed on the employer. The increase in wages could simply be too small in comparison to the employer's obligation to calculate them.

The Court actually obliged Member States to apply the proportionality test in the strict sense. This means they have to weigh the costs for the employers in comparison to the benefits for the posted workers. Imposing the test, the Court actually stressed that the interests of workers do not take precedence over the interests of employers.

In Mazzoleni, new restrictions were imposed on the right to extend national legislation to posted workers. Member States have to take into consideration the overall position of posted workers, calculating taxation and social security contributions in the minimum wage. They also need to evaluate the real benefits for posted workers in relation to the costs for employers.

The test of proportionality seems to be quite new in the Court's case law regarding minimum wages, although it was mentioned in Arblade (though not applied). The Court found the test useful in Mazzoleni since it was of the opinion that it was a special circumstance concerning an undertaking established in a frontier region. It could thus be concluded that imposing minimum wages on foreign service providers is in most cases proportionate (since the Court did not use the test in Arblade). However, Member States have to take additional care and use the test when they intend to impose a wage in special circumstances like the one which arose in Mazzoleni. Such special circumstances have not been enumerated by the Court so far and the safest solution for the authorities would be to apply the proportionality test in each case since any case might be a special circumstance.

\section{Portugaia Construções and Laval - respecting equality}

Arblade and Mazzoleni were cases about minimum wages which had been prescribed by collective agreements declared universally applicable. In Portugaia Construções ${ }^{10}$ and Laval another problem concerning the unequal treatment of foreign and domestic employers arose. Portugaia was a case about a collective agreement establishing minimum wages which had to be observed by all foreign undertakings, but at the same time did not have to be observed by those domestic undertakings which had signed a different collective agreement. Therefore, they could agree on lower wages than the "minimum". Laval concerned a Swedish law precluding trade unions from starting collective action against those employers paying their workers wages lower than the "usual" but which had signed collective agreements. At the same time, it allowed such collective

10 Case C-164/99 Portugaia Construções L $d^{\underline{a}}$ [2002] ECR I-00787. 
action against foreign employers (the facts of the case are presented in more detail in the second part of the article).

In both cases, the Court found the measures to be directly discriminatory and that they could only be justified by express Treaty provisions, not by overriding reasons relating to public interest. Thus, neither in Portugaia nor in Laval could a Member State invoke the protection of workers, since this is not considered by the Court as grounds for public policy. It is quite obvious why the Court narrowed the grounds for the justification of such measures. They are intended to protect domestic employers rather than workers. Such a goal was considered by the Court in Portugaia to be an economic aim and therefore unacceptable.

If a Member State truly had the protection of workers as its objective then, for example, in Portugaia, Germany would have extended the minimum wage to all domestic workers, and in Laval, Sweden would have allowed collective action against domestic employers who had signed collective agreements, and not only against foreign employers.

To summarise, Member States, although free to extend their legislative provisions or collective agreements on minimum wages, have to exercise a certain degree of restraint. Minimum wages and any other legislation in relation to wages has to be applied equally to foreign and domestic service providers. Such a measure has to be made accessible to foreign employers so they may become acquainted with the minimum wage which is to be applied to them. The necessity of such measures needs to be assessed in the light of taxation and social security contributions and it should not become a disproportionate burden for the employer.

Overall, it seems that the Court limited its approach in Rush Portuguesa, which gave Member States quite broad possibilities to extend their legislation on minimum wages to foreign services providers. In Arblade, it enhanced the cross-border provision of services by introducing the principle of legal certainty when minimum wages are being applied. On the other hand, in Mazzoleni, the Court emphasised that in certain circumstances minimum wages of a host Member State cannot be applied to foreign service providers at all due to the fact that it might constitute a disproportionate measure.

So far we have seen the limits within which Article 49 has kept Member States' autonomy to extend their legislation to foreign service providers. Turning to the Posted Workers Directive, we shall now analyse how the situation has changed because of the new restrictions that the Directive imposes and see how Member States have acclimatised to it.

\section{The Posted Workers Directive}

After the Court's ruling in Rush Portuguesa, Member States were left with the impression that they were free to impose their legislation upon 
foreign service providers. However, when the Commission proposed the first draft of the future Posted Workers Directive, this sense of security was proved to be false. ${ }^{11}$

\section{The aim of the Directive}

Directive 96/71/EC of the European Parliament and of the Council concerning the posting of workers in the framework of the provision of services was adopted on 16 December 1996 and has caused a lot of controversy ever since. It is based on Articles 47(2) and 55 of the Treaty, ${ }^{12}$ and according to the $5^{\text {th }}$ recital of its preamble, is intended to promote the transnational provision of services, at the same time ensuring a climate of fair competition and guaranteeing respect for the rights of workers. Nonetheless, recital 13 reveals the somewhat dubious nature of the Directive's aim. It states that 'the laws of the Member States must be coordinated in order to lay down a nucleus of mandatory rules for minimum protection' of posted workers. One of these, according to Article 3(1)c of the Directive, is the minimum wage. Reading the Preamble and Article 3(1) we are faced with the question - is the Posted Workers Directive just aimed at facilitating the free provision of services, or does it also aim to create some substantive rights for posted workers?

This, at first glance, theoretical doubt, can be of crucial importance. As can be seen from Article 3(1), Member States must ensure that undertakings which post workers to their territory respect certain conditions of employment which are laid down by laws, regulations or administrative provisions and, in the building sector, also by collective agreements declared universally applicable, as defined in Article 3(8)2. However, what if a Member State has neither legislation nor universally applicable collective agreements concerning the minimum wage like Sweden or Italy? Would it then be obliged to enact any? If we take the stand that the Directive only identifies the mandatory rules in force in the host Member State, than that Member State would certainly not have to introduce any new legislation. The aim of the Directive, ie facilitating transnational provision of services, is in this case achieved as it is clear for foreign undertakings that they do not have to pay the host state's minimum wage (because there isn't one). Such a situation is almost perfect for them because no additional burden is placed upon them, neither an administrative nor economic one. It can also be argued that both posted and domestic work-

\footnotetext{
11 For further readings on the carving of the Directive see Paul Davies, 'European Developments - The Posted Workers Directive and the EC Treaty' (2002) 31 ILJ 298; Paul Davies, 'Posted Workers: Single market or protection of national labour law systems?' (1997) 34 CMLR 571-602.

12 Former EC Treaty articles 57(2) and 66 concerning the free provision of services.
} 
ers are provided with the same opportunity to negotiate their wages and that therefore the equal treatment of posted and domestic workers is achieved.

On the other hand, if we are to say that the aim of the Directive is to facilitate the provision of services as well as to protect the rights of workers, we would come to a different conclusion and say that a Member State would have to enact new legislation. Only by doing so could such a Member State offer sufficient protection to workers, because otherwise posted workers would enjoy no protection at all regarding the host Member State. ${ }^{13}$ However, one might object that the Directive is based on Articles regarding the free provision of services and not on those regarding social rights. How could it then protect workers as well? Perhaps the answer can be found in Defrenne II ${ }^{14}$ and Viking ${ }^{15}$ where the Court emphasised that the European Union is not merely an economic union, but also a social one. In addition, according to British American Tobacco, ${ }^{16}$ a directive can pursue additional aims besides those which it is based on. Finally, a piece of legislation has to strike a fair balance between the various interests concerned, ${ }^{17}$ and the Posted Workers Directive can do so only if it protects the rights of workers as well as those of service providers.

\section{The implementation of the Directive}

When implementing the Posted Workers Directive and therefore determining the minimum wage applicable to posted workers, a Member State must make sure to do so in a way which respects the general rules of implementation. Therefore, it must implement it in a clear and precise manner which allows individuals to be fully aware of their rights and obligations. ${ }^{18}$ According to the well established case law, the implementa-

\footnotetext{
13 This might be problematic if the home Member State which posted workers come from uses the same system and prescribes no minimum wages at all. In this case, undertakings which post workers are formally not obliged to pay any minimum rate of pay. Since, on the one hand, domestic workers de facto enjoy a certain level of pay which they negotiate in practice, and on the other, posted workers are not protected at all because of their weak negotiating powers, this situation in practice leads to discrimination against posted workers.

14 Case 43/75 Gabrielle Defrenne $v$ Société anonyme belge de navigation aérienne Sabena [1976] ECR 00455 par 10.

15 Case C-438/05 International Transport Workers' Federation and Finnish Seamen's Union $v$ Viking Line ABP and OÜ Viking Line EestiViking Line [2007] ECR 00000 par 79.

16 Case C-491/01 The Queen $v$ Secretary of State for Health, ex parte British American Tobacco (Investments) Ltd and Imperial Tobacco Ltd [2002] ECR I-11453 par 82.

17 Commission (EC), 'Posting of workers in the framework of the provision of services: maximising its benefits and potential while guaranteeing the protection of workers' (Communication) SEC (2007) 304 final 13 June 2007 par 2.1.

18 Case 102/79 Commission of the European Communities $v$ Kingdom of Belgium [1980] ECR 01473 par 11; Case C-131/88 Commission of the European Communities $v$ Federal Republic of Germany [1991] ECR I-00825 par 6.
} 
tion may be left to social partners and done by collective agreements. ${ }^{19}$ This Directive is no exception. What is more, its very provisions ${ }^{20}$ say that the terms and conditions of employment for posted workers are to be laid down by laws, regulations, administrative provisions, and in some cases even by collective agreements or arbitration awards that have been declared to be of universal application. At this point we must take into consideration the differences in the social models of various Member States.

\section{2. a) Regulating the minimum wage through legislative provisions}

Some Member States, like France, Greece and Spain, regulate the minimum wage through legislative provisions. These Member States have a rather easy task when implementing the Directive - they should make it clear from their legislation that the prescribed domestic minimum wage applies to posted workers as well. In other words, these Member States only have to extend their way of determining minimum pay to posted workers. The result is that all the workers on their territory, both domestic and posted ones, are subject to the same regime regarding the minimum wage. This is very satisfactory from the perspective of the principle of equality and is an effective form of prevention of social dumping, though only up to a certain point. As recital 13 reminds us, this Directive is only meant to ensure certain minimum terms and conditions of employment for posted workers. Therefore, since it can only ensure equal minimum wages and not equal pay in general, it cannot completely eliminate the possibility of social dumping, but can only reduce it. Some of the older Member States might not feel comfortable with this, while newer ones might find the Directive's solution suitable for exploiting their competitive advantage of a cheaper workforce. The Directive actually offers a compromise between these two interests, a compromise which the Court recently confirmed. ${ }^{21}$

\section{2. b) Regulating the minimum wage through collective agreements}

Article 3 states that the Directive can be implemented through collective agreements which have been declared universally applicable. Paragraph 8 of the same Article is more specific about the meaning of the term "universally applicable". It says that these are collective agreements which "must be observed by all undertakings in the geographical area and

\footnotetext{
19 Case C-143/83 Commission of the European Communities v Kingdom of Denmark [1985] ECR 00427 par 8; C-234/97 Teresa Fernández de Bobadilla v Museo Nacional del Prado, Comité de Empresa del Museo Nacional del Prado and Ministerio Fiscal [1999] ECR I-04773 par 19.

20 Article 3(1) of the Posted Workers Directive.

${ }^{21}$ Viking Line (n 15) and Laval (n 7) cases.
} 
in the profession or industry concerned'. No problems occur for Member States if they have a system for declaring collective agreements universally applicable and have used the system for their own workers, as they only have to declare the collective agreements universally applicable to posted workers as well. This will result in the equality of treatment of both posted and domestic workers. It is also quite convenient for foreign undertakings which post workers, because the applicable minimum wage can easily be determined. A number of Member States, like Germany and Austria, chose to implement the Directive in this way.

Still, some Member States do not have a system for declaring collective agreements universally applicable. Can they nevertheless implement the Directive through collective agreements? The second subparagraph of Article 3(8) gives an affirmative answer. These Member States have an option to base themselves on collective agreements "which are generally applicable to all similar undertakings in the geographical area and in the profession or industry concerned' or those 'concluded by the most representative employers' and labour organizations at national level' and applied throughout national territory. If they decide to do so, they must explicitly say so in their legislation implementing the Directive. Only then is the requirement of clear and precise implementation satisfied. However, it is important to stress that the option provided for in Article 3(8)2 can only be used if a Member State has no system for declaring collective agreements universally applicable..$^{22}$ According to the Commission's Communication from 2003, ${ }^{23}$ none of the Member States made use of this option so it remained only a theoretical possibility, and a contentious one. Perhaps the best way to show why is to analyse the Laval case.

\section{The Posted Workers Directive and Article 49 - the cases of Laval and Dirk Rüffert}

\section{3. a) Laval}

Sweden was one of those Member States which had no system for declaring collective agreements universally applicable and which did not use the option in Article 3 (8) to rely on generally applicable collective agreements. It has a tradition of non-interference in labour relations regarding wages, so it left the trade unions to negotiate the wages with foreign employers, as they do with domestic ones. That is just what happened in Laval. A Latvian undertaking posted approximately 35 of its workers on a building site in Sweden. It had previously signed a collective

\footnotetext{
22 The Court confirmed this in case C-346/06 Dirk Rüffert $v$ Land Niedersachsent [2008] ECR 00000 par 27.

23 Commission (EC) 'The implementation of Directive 96/71/ EC in the Member States' (Communication) COM (2003) 458 final 25 July 2003.
} 
agreement with a Latvian trade union. However, it did not sign a collective agreement with the Swedish trade unions. Swedish trade unions requested an hourly wage based on statistics for that region and that profession and they requested that Laval sign a collective agreement regarding other terms and conditions of employment. When Laval refused, the trade unions made a new offer and agreed to negotiate the wages with Laval if it signed an agreement which had a so-called fall-back clause. The wage from such a clause, which is lower than the usual one for that profession and region, is used if negotiations on wages fail. Since the negotiations were unsuccessful, the trade unions started collective action by blockading the building site where Laval worked. Mediation meetings were held during the collective action, but no agreement was reached.

The first legal issue which occurred was whether Sweden had properly transposed the Directive by omitting to prescribe the minimum wage either by law, regulation, administrative provision or collective agreements declared universally applicable. The trade unions argued that Sweden had properly transposed the Directive by leaving the wage to be determined by both sides of industry. In this way, they tried to argue that they had the right to ensure the wage through collective action. The Court concurred with the argument that the Directive does not require the minimum wage to be prescribed by means envisaged by the Directive. It expressly stated that it was not the purpose of the Posted Workers Directive to harmonise the systems for establishing terms and conditions of employment. ${ }^{24}$ In other words, Member States do not have to make any changes in their legislation due to the Directive. ${ }^{25}$ However, they will want to prescribe wages in ways envisaged by the Directive, as will be shown later in the text.

The next legal issue which occurred was whether the collective action of the trade unions was a justified restriction on the free provision of services even if the Directive had not been improperly transposed. ${ }^{26}$ It has to be pointed out that the trade unions required negotiations on wages and the signing of collective agreements which related to matters not envisaged by the Directive, since this is of crucial importance in the explanation of the judgement.

The Court firstly made two general statements to provide guidance to Member States on how to legislate on minimum wages if they are to impose them on foreign employers. The first was that no wage except the

\footnotetext{
$24 \quad$ Laval (n 7) par 67, 68.

25 However, Member States have to guarantee posted workers the same level of minimum wages if those minimum wages are prescribed in one of the ways envisaged by the Directive.

26 There were some legal issues in Laval which are not specific to minimum wages, like the scope of application of EC law regarding fundamental rights and the issue of the binding nature of Article 49 on individuals.
} 
minimum may be imposed on foreign service providers ${ }^{27}$ (and no other terms and conditions of employment except those envisaged by the Directive).$^{28}$ Thus, if domestic workers can be paid lower than the amount required for posted workers, then the measure is contrary to the Directive (Laval was first required to pay the average wage for the region and profession, and then after the blockade had started it was required to sign the collective agreement as a condition for starting negotiations on wages). This was in conformity with the Court's judgment in Portugaia Construções where it is stated that such a measure would be directly discriminatory.

The second statement was that the minimum wage has to be prescribed in one of the ways envisaged by the Directive, otherwise it cannot be enforced in respect of posted workers. ${ }^{29}$ Therefore, Swedish negotiations on a case-by-case basis breached the Directive. The reason behind this requirement is, as the Court itself stated, the incapability of foreign employers to ascertain the wages which they are to pay their posted workers. ${ }^{30}$ The Court pointed out that the Directive expressly lays down the degree of protection for posted workers and that otherwise the Directive would be deprived of its effectiveness. It seems that the Court views the Directive as an instrument of simplifying the rules which are to be applied to foreign service providers rather than an instrument for enhanced workers' protection. It could, therefore, be said that the Court finds the added value of the Directive in its pursuit of limiting the ways in which foreign service providers may be obliged to respect the wages of a home Member State. Unlike Article 49, which does not a priori preclude certain ways of prescribing minimum wages, the Community's legislature does exactly this.

After these rather general statements, the Court turned to the question of specific collective action. What the trade unions required were negotiations on pay and certain terms and conditions of employment. The Court recognised that ensuring that the terms of employment are fixed at a certain level falls within the legitimate objective of protecting work-

\footnotetext{
27 Laval (n 7) par 70.

28 The trade unions required, besides the negotiations on wages, certain terms of employment which may be required by the Directive only on grounds of public policy. It was ruled by the Court that only a Member State may rely on grounds of public policy envisaged by the Directive and not trade unions since they are not bodies governed by public law. At first sight, it might seem that only bodies governed by public law may rely on public policy as general grounds for justification. This would be in direct contradiction with the judgment in Case C-415/93 Bosman [1995] ECR I-04921. However, this part of Laval should probably be understood as precluding bodies which are not governed by public law from relying only on these provisions of the Directive and not public policy in general.

29 Laval (n 7) par 70.

30 Ibid par 71.
} 
ers. However, it stated that these specific obligations, precisely because co-ordination has been achieved by the Directive, cannot be imposed on the employer since they go beyond what is prescribed by the Directive. ${ }^{31}$ Therefore, it can be said that the Community's legislature has prescribed what is to be considered as a disproportionate burden for the employer compared to the protection of workers.

The second reason why collective action could not have been justified was that the trade unions required negotiations on pay. In effect, they were not requiring any specific wage. This was considered by the Court to be part of a national context which is not sufficiently precise and accessible for foreign employers to determine their obligations. ${ }^{32}$ The Court actually used the wording from Arblade but in a somewhat different context. In Arblade the Court precluded criminal prosecution because of imprecise provisions while in Laval it was collective action which was precluded. It is understandable why the Court used the principle nullum crimen, nulla poena sine lege, which is actually a specific form of a general principle of legal certainty in Arblade, but it is rather vague why it used it in relations between two private persons like trade unions and an undertaking. ${ }^{33}$ It is possible that the Court considered that the effect of collective action on Laval as an undertaking would have been similar to criminal prosecution. After all, the collective action had been conducted in the form of a blockade disabling construction absolutely and had resulted in the bankruptcy of an undertaking in Laval's ownership. On the other hand, the Court did not use these arguments and it seems that legal certainty is a requirement for any impediment to the free provision of services, even one which is the result of the actions of individuals.

The question now is what Sweden can do to protect its workers from social dumping. The answer is quite simple, as it just has to avail itself of Article 3 (8), which exists specifically for systems like Sweden's. The system has to base itself on collective agreements which are generally applicable to all similar undertakings in the region and in the profession or industry, or it can base itself on collective agreements concluded between labour and employers' organisations at the national level. It can be argued that the Directive significantly changes the current model of case-by-case negotiations, and this is actually what it does, as it makes it absolutely impossible in cases involving the posting of workers. However, on the other hand, it is quite questionable to what extent case-by-case

\footnotetext{
31 Ibid par 107, 108.

32 Ibid par 110.

33 Par 110 of Laval can also be viewed as an application of the test of proportionality, since an imprecise and unclear requirement on the part of trade unions could be seen as a more restrictive measure than a demand for a specific wage.
} 
negotiations are really necessary for workers' protection and the prevention of social dumping. The Community's legislature obviously considers that the wages negotiated in a certain region and profession for domestic workers ought to be enough for posted workers and ought to be enough to prevent social dumping in that Member State. In Sweden, such collective agreements do exist, although they come into force and provide the fall-back wage only if negotiations in situ fail. Thus, these collective agreements provide a level of workers' protection which is guaranteed to all workers in a given profession and region and should be considered as minimal terms and conditions of employment. Therefore, the only way for Sweden to prevent social dumping is to rely on such agreements.

It can be concluded that the model envisaged by the Directive helps all those employers posting workers to ascertain their obligations before posting them, without having an obligation to engage in lengthy negotiations (which they probably had to carry out in their home state). The Court gives the Directive an interpretation which is more beneficial to free movement than to the protection of workers. Another important case that is crucial for the understanding of the Directive is Dirk Rüffert, but as we shall see, some questions, such as the relationship between the Directive and Article 49, still remain unanswered.

\section{3. b) Dirk Rüffert}

A German undertaking subcontracted a Polish one to perform public works in Germany. The Polish undertaking used its own workers and paid them a wage which was lower than the one prescribed by the "Buildings and public works" collective agreement in force in the place where the work was carried out. According to the laws of Land Niedersachsen, a public contract may be awarded only to a tenderer which guarantees to pay its workers the wage prescribed by the "Buildings and public works" collective agreement. Therefore the contract was terminated. However, the problem was that such a collective agreement could not be used to determine minimum wages to be applied to posted workers since it did not fulfil the requirements in the Posted Workers Directive. First of all, it was not declared universally applicable. Secondly, it did not cover the entire construction sector but only public contracts, thus it could not even be considered to be of general application within the meaning of Article 3(8) of the Directive. What is more, generally applicable collective agreements could be relied upon only when a Member State did not have a system of declaring collective agreements universally applicable and Germany did have such a system. Consequently, the Court ruled that imposing a minimum wage determined by such a collective agreement was capable of constituting a restriction on the free provision of services. Let us analyse its arguments more closely. 
The Posted Workers Directive lists minimum terms and conditions of employment that should be guaranteed to posted workers. As confirmed in Laval, a Member State cannot impose on foreign undertakings any other wage higher than the minimum wage. If it could, the Directive would then be deprived of its effectiveness. ${ }^{34}$ Since the German contracting authority did so in a public procurement procedure, the Court in Rüffert repeated its reasoning from Laval. However, a special issue is the fact that this case was about a public procurement contract. Can the Posted Workers Directive influence the area of national public procurement law and change the criteria for the award of public procurement contracts? The Court ruled that it could. Directive 96/71 applies to all situations when undertakings post workers, no matter whether they will be working in the private or public sector. ${ }^{35}$

A separate issue was the fact that in Land Niedersachsen minimum wages were not prescribed according to the procedures laid down in the $\mathrm{Di}$ rective. According to the reasoning in Laval, these minimum wages could therefore not be imposed on foreign undertakings. Of course, this is in line with what the Court had said in Laval - that Member States are free to choose a system for determining the minimum wage which is not expressly mentioned in the Directive. However, they cannot impose minimum wages determined in such a way on foreign undertakings. Therefore, Member States now have a choice - they can either determine the minimum wage in a procedure envisaged by the Directive and then impose them on foreign undertakings, or not determine them in such a way and consequently not have the right to oblige foreign undertakings to pay them.

Yet another point raised in Rüffert concerns the aim of the Posted Workers Directive. The Court explicitly said that it is secondary to the fundamental freedom of provision of services and should therefore be read in the light of Article $49 .{ }^{36}$ Of course, this does not necessarily mean that the Directive has no social purpose at all, but just that its basic and more important goal is to facilitate the free provision of services. This can be seen from the fact that if a Member State has a minimum wage prescribed in a way envisaged by the Directive, it has to guarantee that rate of pay to posted workers as well. The Court further established that imposing rates of pay that are not determined in accordance with the Directive is capable of constituting a restriction of Article $49 .{ }^{37}$ Finally, there is one last question to examine. Could the German authorities justify such an action? Are there any circumstances which would warrant the impo-

\footnotetext{
${ }^{34}$ Laval (n 7) par 80.

35 Dirk Rüffert (n 22) par 20.

36 Ibid par 36.

37 Ibid par 37.
} 
sition of a rate of pay that is higher than the minimum one, and which is not fixed in accordance with the Posted Workers Directive? The Court ruled that in the present case it could not be justified by the objective of the protection of workers. Since the contested collective agreement and therefore minimum wage applied only to construction workers when employed in the context of a public works contract, the collective agreement did not even offer the same level of protection to all domestic workers. ${ }^{38}$ Why should it then be imposed on posted workers, and why would they constitute a threat to domestic workers employed under a public works contract when domestic workers employed elsewhere were not considered to be so? Furthermore, the Court ruled that such a measure was not necessary to avoid the risk of seriously undermining the financial balance of the social security system..$^{39}$ However, if it were necessary, the Court's conclusion might have been different and it might have said that such a measure was justified.

Yet, one cannot help but wonder whether this would be in conformity with the thesis put forward by Advocate General Mengozzi that even though the Directive implements Article 49, not every measure that is in accordance with the Directive will at the same time necessarily be compatible with Article 49. Still, a measure that is incompatible with the Directive will also constitute a breach of Article 49. As the Advocate General puts it, 'the Directive does not exhaust the application of Article $49^{\prime} .^{40}$ If this is the case, why would it be necessary to examine whether a measure breaches Article 49 once it has been determined that it is incompatible with the Directive? And this is exactly what the Court does in Laval and Rüffert. It firstly establishes that the demand of the trade unions in Laval and the method of fixing the rate of pay in Rüffert are not in conformity with the Directive and then goes further and establishes that the measures are also contrary to Article 49. Unfortunately, the Court does not answer this question for us, but only states that it must first "be examined with regard to the provisions of that directive interpreted in the light of Article $49 \mathrm{EC}$, and, where appropriate, with regard to the latter provision itself ${ }^{41}$ One might therefore argue that if a Member State determines the minimum wage in a way which is not in accordance with the Posted Workers Directive, but is still clear and precise enough for foreign undertakings, such a minimum wage would be in conformity with Article $49 .{ }^{42}$ Therefore the Court would have to check every time whether the way

38 Ibid par 39, 40.

39 Ibid par 42.

40 Opinion of AG Mengozzi on Laval [2007] ECR 00000 par 147.

${ }^{41}$ Laval (n 7) par 61.

${ }^{42}$ Such an interpretation might seem to be contrary to paragraph 70 of the Laval judgement and 31 of Rüffert, but nevertheless, seems to be in accordance with paragraph 110 of Laval. 
of determining the rate of pay contravenes the Directive and separately whether it contravenes Article 49. However, for the time being, this question remains unanswered.

To conclude, in the past twenty years the Court has gradually been developing the conditions under which Member States may impose their wages on foreign service providers. The most recent answer is that they may only impose the minimum wage which applies to their own workers and which is set in a clear and precise manner in accordance with the Posted Workers Directive.

Having described the present situation in the European Union, we shall now focus on the situation in Croatia. The following part of the article will deal with the problem of ensuring the minimum wage for posted workers in Croatia in the light of Croatia's obligations and/or rights as a potential candidate to the European Union. We shall begin by examining the nature, interpretation and application of the Stabilisation and Association Agreement which gives Croatia the status of potential candidate.

\section{Minimum wages in Croatia in the light of the Stabilisation and Association Agreement}

When the Court gave its judgments in Laval and Rüffert it also gave an unexpected interpretation of the Posted Workers Directive. Naturally, Member States are bound to respect its rulings. Even though Croatia is not a Member State, it has an obligation to comply with the Community acquis since it gained the status of potential candidate by signing the Stabilisation and Association Agreement (hereinafter the SAA). The Posted Workers Directive is part of the acquis, but what about the Court's rulings that come with the Directive, like Laval and Rüffert? Does the SAA create an obligation to comply with the judgments of the Court as well?

We shall try to answer what the obligations of Croatia are regarding the SAA, but firstly, in order to facilitate understanding of the SAA, we shall explore its nature and purpose.

\section{The nature and purpose of the Stabilisation and Association Agreement signed with Croatia}

For the purpose of ensuring closer ties with Non-Member States, the European Union developed a new form of association agreement, the Stabilisation and Association Agreement, which gives a Non-Member State the status of potential candidate. Croatia signed a Stabilisation and Association Agreement on 29 October 2001, and it came into force on 1 February 2005. This kind of association agreement is based on Article 310 of the EC Treaty, which states that 'The Community may conclude with one or more States or international organisations agreements establishing an 
association involving reciprocal rights and obligations, common action and special procedure. ${ }^{43}$

Association agreements ${ }^{44}$ represent an act of the Community and therefore form an integral part of the Community acquis, as the Court confirmed in the Haegeman judgment: 'The Agreement is therefore, in so far as concerns the Community, an act of one of the Institutions of the Community. The provisions of the agreement form an integral part of Community law'. ${ }^{45}$ Within the framework of this law, the Court has jurisdiction to give preliminary rulings concerning the interpretation of association agreements.

Unlike the previous Europe Agreements, ${ }^{46}$ which were signed with Central and Eastern European Countries, SAAs do not guarantee full membership of the European Union. ${ }^{47}$

The question that inevitably follows is what is the Union trying to do with Stabilisation and Association Agreements? The answer may be considered simple, since the Court held in the Demirel ${ }^{48}$ judgment that

43 To join the EU, a new Member State must meet three criteria (Copenhagen): political: the stability of institutions guaranteeing democracy, the rule of law, human rights and respect for and protection of minorities;

economic: the existence of a functioning market economy and the capacity to cope with competitive pressure and market forces within the Union;

acceptance of the Community acquis: the ability to take on the obligations of membership, including adherence to the aims of political, economic and monetary union.

44 What is more, the Court held in the Sevince judgment that not only association agreements, but also the provisions adopted for the implementation of an association agreement concluded by the Council and a non-member country, form an integral part of the Community legal system in the same way as the agreement itself, so that the Court, which has jurisdiction on the basis of Article 234 of the Treaty to give rulings on the agreement which was adopted as an act of the institutions, also has jurisdiction to give rulings on their interpretation, this being conducive to the uniform application of Community law.

45 Case 181/73 R. \& V Haegeman v Belgian State [1974] ECR 00449 par 4, 5.

46 Europe Agreements were mixed agreements, that is they were agreements concluded with a third state and to which the European Communities were party as well as its member states. Europe Agreements were based on a mutual understanding and the shared values peculiar to the European Community and the associate state. They prepared the way for economic, political, social and cultural convergence between the Union and its partners.

47 The original text of Europe Agreements was not formulated in a way which would guarantee full membership. However, the European Council in Copenhagen (1993) acknowledged accession/membership as a mutual goal of the Union and the contracting parties. Later on, in Essen (1996) the Council gave new meaning to the Copenhagen strategy, which made the EA a part of the accession process. Thus, the preamble of the European Agreements signed with Estonia, Lithuania, Latvia and Slovenia signed after Essen have an additional paragraph. For example, the Europe Agreement signed with Slovenia states in the last paragraph of the preamble: "Recognising the fact that Slovenia's ultimate objective is to accede to the European Union, and that this Association, in the view of the parties, will help Slovenia to achieve this objective."

48 Case 12/86 Meryem Demirel v Stadt Schwäbisch Gmünd [1987] ECR 03719 par 9. 
association agreements create special rights and privileged links with a non-member country which must, at least to a certain extent, take part in the Community system. Does this mean that the Union is recruiting without following through? Is the Union performing some kind of initiation process knowing that the participant list is full? To what end do SAAs extend?

The answer to these questions may be found in the Declaration endorsed in Thessaloniki on 21 June 2003, which explicitly states:

The EU reiterates its unequivocal support to the European perspective of the Western Balkan countries. The future of the Balkans is within the European Union. Preparation for integration into European structures and ultimate membership into the European Union, through adoption of European standards, is now the big challenge ahead. ${ }^{49}$

Does this mean that the nature of the SAA with Croatia has reached a new level? May the SAA now be acknowledged as an instrument for attaining full membership as a mutual goal of the Union and Croatia?

Let us go back to the text of the preamble of the SAA signed with Croatia, which in a way repeats the sense of the Court's judgment in Demirel:

... the European Union's readiness to integrate to the fullest possible extent Croatia into the political and economic mainstream of Europe and its status as a potential candidate for EU membership subject to the successful implementation of this Agreement, notably regarding regional co-operation. ${ }^{50}$

Thus, co-operation depends on Croatia and its readiness to direct its activities towards the attainment of full membership, which, however is not guaranteed, or, in fact, can it be considered that it is?

What is more, by signing this agreement, Croatia undertook the obligation to ensure that existing laws and future legislation will be made compatible with the Community acquis. ${ }^{51}$ Since the Court's case law also constitutes an integral part of the Community acquis, this obligation also includes co-ordination with the judgments of the Court. ${ }^{52}$

\footnotetext{
49 Thessaloniki 21 June 2003. 10229/03 (Presse 163), <http://www.cespi.it/STOCCHIERO/dossierBalcani/dich-Salonicco.PDF> accessed 25 June 2008.

50 The Stabilisation and Association Agreement between the European Communities and their Member States, and the Republic of Croatia; preamble.

51 Article 69 of the Stabilisation and Association Agreement: The Parties recognise the importance of the approximation of Croatia's existing legislation to that of the Community. Croatia shall endeavour to ensure that its existing laws and future legislation will be gradually made compatible with the Community acquis.

52 See the judgment of the Constitutional Court of Croatia No U-III-1410/2007 and more in the conclusion.
} 
A more interesting question is whether agreements signed between the Community and third parties confer rights to individuals which national courts are bound to protect. An explanation was given in the Demirel judgment:

... a provision in an agreement concluded by the Community with non Member State countries must be regarded as being directly applicable when, regard being had to its wording and the purpose and the nature of the agreement itself, the provision contains a clear and precise obligation which is not subject in its implementation and effects to the adoption of any subsequent measure. ${ }^{53}$ (emphasis added)

As we can see, the Court accepted the same criteria for the direct effect of international agreements (clear and precise) as it used for the direct application of the Treaty and secondary legislation, beginning with Van Gend en Loos. ${ }^{54}$ Thus, if the provision of the SAA is clear and precise it confers rights to individuals which national courts of Member States are bound to protect.

We must bear in mind, however, that although Stabilisation and Association Agreements form an integral part of the Community acquis, and even though their provisions may have a direct effect, they are still international agreements and can be interpreted in a different way by each contracting party. Thus, SAAs sometimes may not be interpreted in the same way as Community legislation. They have to be interpreted in the light of their nature and purpose..$^{55}$

\section{Ensuring the minimum wage for posted workers, obligations or/ and rights in the light of the SAA}

The whole debate over the obligations of Member States regarding minimum wages in the light of the Posted Workers Directive sheds another, new light on the obligations or rights of a Non-Member State which has signed an SAA and attained the status of a potential candidate, and thus committed itself to the approximation of its existing legislation to that of the Community.

\footnotetext{
53 Demirel (n 48) par 14.

54 Sinisa Rodin, 'Stabilisation and Association Agreement in the Legal Order of the European Community and the Republic of Croatia' (2003) 53 ZPFZ 3, 4.

55 Case 270/80 Polydor Limited and RSO Records Inc v Harlequin Records Shops Limited and Simons Records Limited [1982] ECR 00329. However, it must be noted that the nature and purpose of the provisions of the SAA are sometimes the same as the nature and purpose of the relevant Treaty provisions (see case C-265/03 Igor Simutenkov v Ministerio de Education y Cultura [2005] ECR I-02579 and case C-438/00 Deutscher Handballbund eV v Maros Kolpak [2003] ECR I-04135).
} 
The following question arises: what are the obligations or rights of a Non-Member State potential candidate regarding minimum wages for posted workers?

\section{2. a) The present regulation of the minimum wage in Croatia}

While this article was in the process of being written, the Croatian Parliament enacted the Minimum Wage Act. The Act came into force on 1 July 2008.

The social and economic situation in Croatia has changed the views of trade unions regarding the previous regulation of the minimum wage through collective agreements. According to the Union Association of Independent Trade Unions of Croatia (UATUC), ${ }^{56}$ the weak negotiating position of Croatian trade unions has led them to the conclusion that only an act on minimum wages can and will solve the problem of not respecting the collectively bargained minimum wage. Thus, the trade unions proposed a new act on minimum wages.

The Act has no explicit provision referring to its applicability to posted workers. As stated in the text of the Act, the minimum wage is to be guaranteed to all workers who work in Croatia. ${ }^{57}$ Such a provision may be read in a way that it equally, though indirectly, refers to posted workers since they will also work in Croatia, even if only temporarily. ${ }^{58}$

Prior to the enactment of the Minimum Wage Act, Croatia fell within the group of Member States like, for example, Austria, Denmark and Germany, in which minimum rates of pay are regulated by collective agreements. ${ }^{59}$ In Croatia, however, the term used was the lowest wage and not the minimum wage. The Collective Agreement on the lowest wage was signed on the 6 March 1998. On the basis of the Decision of the Minister of Labour and Social Security, the collective agreement in question was declared universally applicable, ${ }^{60}$ that is its application was extended to

\footnotetext{
56 The proposal on the Minimum Wage Act: <http://www.sssh.hr/index.php?option=com_ content\&task=view\&id=136\&Itemid=78> accessed 30 June 2008.

57 Article 3 of the Minimum Wage Act ' lanak 3. Pravo na minimalnu pla u, prema odredbama ovoga Zakona, imaju svi radnici koji rade u Republici Hrvatskoj’.

58 It is, however, possible that the Croatian legislature did not have this in mind when it was writing the text of the Act. The Chapter of the Association process that refers to legislation of the European Union, which includes the Posted Workers Directive, was opened on 17 June 2008, and the Act was enacted less than a month before on 30 May 2008.

59 The lowest wage, which in practice, is identified with the minimum wage, depended on the average wage multiplied by a coefficient of 0.35 , which constitutes the lowest monthly base, as determined by the Contribution of Compulsory Insurance Act. The average wage was calculated on the basis of the monthly wage paid per one employed person in a legal person in Croatia during the period from January to August of the current/liquid year as published by the Central Bureau of Statistics.

60 'Collective agreements or arbitration awards which have been declared universally applicable' means collective agreements or arbitration awards which must be observed by all
} 
all employers and employees in Croatia. Therefore, Croatia had one of the systems provided for in the Directive, a system for declaring collective agreements universally applicable, and had used it on its own workers. Thus, Croatia as a Member State would have had the obligation to extend that collective agreement to all posted workers in accordance with Article 3 (1) of the Directive.

We must bear in mind that collective agreements are more flexible and thus are easier to alter. ${ }^{61}$ Since, however, the workers have a "weak" negotiating position, the level of efficient protection of workers through collective agreements is significantly lower. Even though acts are more difficult to amend, the protection of workers by legislative acts is somewhat higher. ${ }^{62}$

The new Minimum Wage Act explicitly establishes very high pecuniary penalties up to HRK 100,000 (approximately EUR 13,870) for noncompliance with the proscribed minimum wage.

\section{2. b) Obligations and/or rights arising from the SAA}

We believe that the obligations or rights arising from the SAA do not differ that much, especially regarding the minimum wage for posted workers, from the obligations Croatia will have as a Member State.

Firstly, Croatia has the duty to approximate laws, competition rules and law enforcement, which arises from Article 69 of the SAA. This states:

The Parties recognise the importance of the approximation of

Croatia's existing legislation to that of the Community. Croatia shall endeavour to ensure that its existing laws and future legislation will be gradually made compatible with the Community acquis.

Even though there is no direct obligation resulting from this Article, the undertaken political obligation necessitates the legal obligation as well, and is binding on Croatian courts.

Secondly, the political ties between the Union and Croatia have grown stronger as a result of the Declaration adopted in Thessaloniki on

undertakings in the geographical area and in the profession or industry concerned (Article 3 (8) of the Posted Workers Directive).

${ }^{61}$ If there is more then one union in a field where a collective agreement is to be concluded, an employer or employers' association can bargain only with a collective bargaining committee composed of representatives of such unions (Art 186(1) Labour Act). If unions cannot reach an agreement on the number of members of the collective bargaining committee, the decision shall be made by the Chairman of the Economic and Social Council, taking into consideration the number of the unions' members. On the request of the chairman of the Economic and Social Council, the employer and employers' association have to provide him with all the data they have on the number of the unions' members (Art 186 (4)).

${ }^{62}$ Ivana Grgurev, 'Collective agreements in Croatia' <http://www.juridicum.su.se/stockholmcongress2002/> accessed 5 June 2008. 
21 June 2003, ${ }^{63}$ which recognised that the future of our region is within the European Union. Moreover, preparations for integration into European structures and ultimate membership of the European Union through the adoption of European standards have been at the top of the political agenda in Croatia during recent years.

Finally, according to Article 56 of the SAA, Croatia has a duty to take the necessary steps to progressively allow the supply of services and, according to Article 57, will not take any measures or actions which render the conditions for the supply of services more difficult. However, it is questionable whether Articles 56 has a direct effect, because it is subject and closely linked to the process of the liberalisation of services in the EU and to the activities of the Association and Stabilisation Council. ${ }^{64}$ Still, the liberalisation of services in the European Union has recently been reinforced by the adoption of the new Services Directive 2006/123, so it might be claimed that Article 56 has a direct effect. ${ }^{65}$ On the other hand, Article 57, which is a stand-still clause, has a direct effect because it is a precise, clear and unconditional provision. ${ }^{66}$

In the light of the above-mentioned reasons, we consider that Croatia, as a potential candidate, has the right, and not so much the obligation, stemming from the SAA to apply the provisions of the Minimum Wage Act to posted workers.

Croatia has the right to apply the same Act to posted workers, but all the reasons mentioned above are too unclear and imprecise as to whether they are sufficient to create a real obligation.

More importantly, since the SAA is an international agreement, Croatia as a contracting party is free to determine the legal means appropriate for attaining the end pursued by the same agreement. ${ }^{67}$ Thus, whether Croatian courts will interpret the Minimum Wage Act as being applicable to posted workers and thus protect their rights is yet to be seen. The Croatian legislature has used a wide formulation, as has been mentioned, for the obligation of ensuring the minimum wage.

Applying the Minimum Wage Act to posted workers would be the best solution when taking into account Croatia's obligation to integrate to the fullest possible extent into the political and economic mainstream

\footnotetext{
63 Thessaloniki 21 June 2003. 10229/03 (Presse 163), <http://www.cespi.it/STOCCHIERO/dossierBalcani/dich-Salonicco.PDF > accessed 25 June 2008.

${ }^{64}$ Iris Goldner, Sloboda kretanja ljudi u EU, Kontekst Sporazuma o pridruživanju (Zagreb 2007) 33-49.

65 They have a stand-still clause character.

66 Iris Goldner, Sloboda kretanja ljudi u EU, Kontekst Sporazuma o pridruživanju (Zagreb 2007) 113.

67 Case 104/81 Hauptzollamt Mainz v CA Kupferberg \& Cie KG a.A [1987] ECR 3641 PAR.
} 
of Europe. Finally, as we have seen, Croatian legal solution for ensuring the minimum wage for domestic workers is appropriate for ensuring the same wage for posted workers. In this way, posted workers will be guaranteed at least the Croatian minimum wage, naturally if it is higher than the minimum wage of the Member State from which the workers are posted.

In the end, foreign service providers and posted workers depend on the willingness of Croatian courts to interpret the wide formulation used by the Croatian legislature and guarantee the proscribed minimum wage.

\section{Conclusion}

The freedom to provide services, as one of the fundamental freedoms upon which the Union is based, plays a crucial role in the Union's economy. Services participate to the extent of almost $70 \%$ of States' GNP. ${ }^{68}$ This being a large amount of money, one cannot be wrong when assuming that it is bound to be an object of various interests. One of these can be found in Member States' desire to control the influence of foreign service providers on their social stability and own national service providers. Surely, the minimum wage is one of the ways in which a Member State can influence the movement of services within its territory. Since it is also is an important instrument of Member States' social policy, it is the one that they are not likely to make compromises over. In contrast, the interests of the Union lie in the liberalisation of the provision of services. However, differences in minimum wages and in methods of establishing them can stand in the way of this goal. This is why the European Court of Justice has set certain boundaries to the application of host Member States' minimum wages to foreign services providers. First, the Court tested the water in Rush Portuguesa and led us to believe that there were no boundaries at all. However, in later judgements, Arblade, Mazzoleni and Portugaia Construções, the Court applied the general principles of non-discrimination, legal certainty and proportionality to the host State's regulation of minimum wages and its enforcement. The Posted Workers Directive brought more challenges, but the unpredictable came with Laval.

The judgement itself made a huge difference to Member States like Sweden which do not regulate a minimum wage. Furthermore, it restricted the exercise of the fundamental right to strike and last but not least, it stirred the existing status of economic and social rights in the Union. The

\footnotetext{
68 Economic assessment of the barriers to the internal market for services, Final report January 2005, Copenhagen Economics, <http://ec.europa.eu/internal_market/services/ docs/services-dir/studies/2005-01-cph-study_en.pdf> accessed 6 July 2008.
} 
difference that The Posted Workers Directive and Laval have made for Member States' social systems is a rather indirect one. Even though the Directive does not harmonise the mandatory rules for minimum protection, ${ }^{69}$ it actually forces Member States to set a minimum wage in the way envisaged by the Directive. Otherwise, for the time being, it seems that a Member State cannot impose such a minimum wage on foreign service providers and therefore cannot confront the challenges of social dumping..$^{70}$ Regarding the way that Laval restricted the fundamental right to strike, it has to be noted that the Court imposed the principle of legal certainty upon private persons exercising their fundamental right. Thus, an important instrument for ensuring a certain wage level has been considerably restrained. Adding restrictions to the social side of the European pendulum has resulted in the ever-growing sentiment of European citizens that the Union is first of all an economic union and only afterwards a social one.

Who benefits from such a shift? While most of the old Member States have a long tradition of protecting social rights and thus have a higher level of minimum wages, newer ones try to benefit from their main competitive advantage - a low-cost workforce. With its rulings in Laval and Rüffert, the Court revealed a hidden paradise for undertakings from these new Member States. They are now free to profit from the lack of regulation of minimum wages in accordance with the Posted Workers Directive in several Member States, such as Sweden. Will Croatia be one of these new Member States?

If the cake is the whole EU market, does the Union really need to ask us "Would you like a piece of it?" The European Union provides the possibility and Croatia must take it. The Union's initiation process however is not an easy one. Croatia's recruitment began with signing the SAA in 2001 and is still in progress. At the time of writing this article, Croatia has opened a new Chapter of its accession to the EU which refers to legislation of the European Union including the Posted Workers Directive. Only a few weeks earlier, Croatia had enacted the Minimum Wage Act on the initiative of Croatian trade unions which had proposed the act in question. Trade Unions were led by two factors - their weak negotiating position and the fact that 20 out of 27 Member States have some kind of legislation on minimum wages.

A separate question is whether Croatia has an obligation and/or right to ensure the minimum wage for workers that are posted to its territory by a Community service provider. That is, how far does the SAA signed with the EU go? Croatia has the right to apply the Minimum Wage

69 Laval (n 7) par 60.

70 For a full insight into the ambiguity of this question refer to point II. 3 . b) of this article. 
Act to posted workers and this right can be protected by Croatian courts. The Croatian legislature uses a wide formulation: 'the minimum wage is to be guaranteed to all workers who work in Croatia'. Thus, it can be concluded that the aforementioned provision refers to posted workers as well, since they will also work in Croatia, even if only temporarily.

Furthermore, there is a tendency in Croatia's Constitutional Court to make sure that the interpretation of the European Court and the legal terms developed within the Union and used in the SAA are respected. It seems that the Constitutional Court also takes into account the context in which the Acts were enacted, that is, the context of ensuring the compatibility of laws and regulations with the Community acquis. What is more, when interpreting Croatian legislation, Croatian courts have an obligation to take into account to the fullest possible extent the interpretation of Community Institutions. The Constitutional Court, however, set boundaries to this interpretation in its judgment U-III-1410/2007. The boundaries are that the interpretation must be in the light of the Croatian legal order and that it must not be contrary to explicit solutions provided for in legislation.

It can be concluded that the provisions of the Minimum Wage Act and the case law of the Constitutional Court currently provide firm foundations for the proper implementation of the Posted Workers Directive in Croatia. Certainly, Croatia is also well motivated to harmonise its legislation with that of the Community as soon as possible. Undertakings which post workers, as well as posted workers themselves, will therefore hopefully not have any problems regarding the determination of the minimum wage level while working in Croatia. 